\title{
Extended Release Film Coated Capsule Dosage Form
}

National Cancer Institute

\section{Source}

National Cancer Institute. Extended Release Film Coated Capsule Dosage Form. NCI

Thesaurus. Code C42928.

A capsule covered with a thin layer of water soluble or insoluble polymer and is designed to release active and/or inert ing redient(s) at a controlled, prolonged rate so as to reduce dosing frequency. 